\title{
Scientific financial funding in Colombia from 2000 to 2012
}

\author{
Jorge Mario Rodríguez-Fernández $\bowtie$
}

\begin{abstract}
This study evaluates trends in funding for Science, Technology and Innovation, Research and Development and COLCIENCIAS (Administrative Department for Science, Technology and Innovation) between 2000-2006 and 2007-2012. Available data from the World Bank, OCY'T (Colombian observatory of science and technology), DANE (National statistics department), Banco de la República and COLCIENCIAS to evaluate funding source by sector (private, public and international), financial growth rate, financial expenditure, and activity related expenses from 2000 to 2012, and regression models to estimate financial trends. COLCIENCIAS funding increased in the past years; Science, Technology and Innovation, and Research and Development funding increased from $\$ 1,296.7$ million US dollars in 2000-2006 to \$2,766.4 million US dollars in 2007-2012. The financial analysis showed a significant increase in public funding mainly by government $(\mathrm{p}<0.05)$; however, government and corporation expenditure did not vary from 2000 to 2012.
\end{abstract}

Keywords: Scientific research and technological development; Research financing; Health sciences; Technology and innovation management; Colombia.

Edited by Alberto Acosta

Assistant Research Scientist - Anxiety Disorders Clinic NYSPI Columbia University Medical Center, NY, USA

Received: 03-09-2013 Accepted: 28-10-2013

Published on line: 12-11-2013

Citation: Rodríguez-Fernández JM (2013) Scientific financial funding in Colombia from 2000 to 2012. Universitas Scientiarum 18(3): 311-320 doi: 10.11144/Javeriana.SC18-3. sffc

Funding: N/A

Electronic supplementary material: N/A

SICI: 2027-1352(201309/12)18:3<311:SFFICF2T2 > 2.0.TS;2-6

\section{Introduction}

Funding for scientific and technology has provided secondary benefits to health and socioeconomic development, as well as to culture and education (North \& Bárcena 1993, Sachs 2001, Frank \& Nason 2009). Research funding comes from both public and private sources. Private funds are usually directed towards commercial purposes and public funds to social interests; however, the goals and benefits of both are not mutually exclusive (Maceira et al. 2010).

Scientific research in Colombia dates back to colonial times. In 1783, a 30-year project describing the natural diversity of Santa Fe (currently, Bogotá D.C) and its environs was conducted under José Celestino Mutis; leading to the collection and classification of thousands of animals and 
vegetables species. Then, in the mid XIX $\left(19^{\text {th }}\right)$ century, Agustín Codazzi and Manuel Ponce de León conducted a cartographic description of the existing territory (Obregón 1991).

Scientific projects prior to the 20th century were conducted without major external involvement or funding. This began to change following the formation of several non-governmental institutions and universities in the $20^{\text {th }}$ century. In 1968, the "Francisco José de Caldas" Scientific Research and Special Projects Fund was created under COLCIENCIAS (Ospina Bozzi 1998). Presently, COLCIENCIAS is the entity responsible for the development of science and technology in Colombia and is the largest funding source in the country. To create a better interaction between COLCIENCIAS and government, the National Science Technology and Innovation Council (CSTIS) was founded. Legislation in the past two decades has made COLCIENCIAS and CSTIS the main policy regulators of the Colombian Science, Technology and Innovation (STI) system.

Because of their positive impacts on industry, education and culture, STI and Research and Development (RD) systems have receive increased attention in recent times (Sachs 2001, Frank \& Nason 2009). Despite this, few studies have focused on the fluctuations in funding of STI and RD in Colombia in the last twelve years; some studies have described this pattern by area of interest (Moses III et al. 2005, Dorsey et al. 2010, Garro et al. 2010, Maceira et al. 2010, Yagui et al. 2010, Martínez-Martínez et al. 2012). The present work will assess: (1) STI and RD patterns by the private, public and international sectors, (2) trends in STI funding, activities, and expenditure in Colombia (3) trends in funding by COLCIENCIAS.

\section{Materials and Methods}

Sources of data: Reports from 2000 to 2012 were taken from 2000 to 2012 from public and nonprofit institutions such as the OCyT (Colombian observatory of science and technology), DANE (National statistics department), and the Banco de la República and COLCIENCIAS and profit organizations like the World Bank Group.
Colombian scientific funding was divided into an early (2000 to 2006) period and a late period (2007 to 2012), as in Dorsey et al. (2010) given that the main goal of this study is to describe and characterize the differences between these two periods.

STI and RD funding was categorized as public, private, and international. To further classify STI, data and grouped the data following OCyT 2012 categories (Salazar et al. 2010, Lucio et al. 2012) by (1) Corporations, (2) Government, (3) Education institutions, (4) International, (5) Research centers, (6) Medical centers, (7) Private non-profit and (8) Professional associations and NGOs (Salazar et al. 2010, Lucio et al. 2012); information on these categories for $\mathrm{RD}$ are not available. STI expenditure (excluding international) was also analyzed; activity related expenditure was categorized as (1) Research and development, (2) Innovation, (3) Administrative related activities, (4) Support for scientific training, (5) Scientific and technological services (Lucio et al. 2012).

Values reported Colombian pesos were converted to US dollars (annual exchange average). As suggested by Bénassy-Quéré \& Roussellet (2012) and Martínez-Martínez et al. (2012), we used a PPP conversion factor (GDP, Gross domestic product) to market exchange rate ratio (The World Bank Group 2013a) for comparative purposes. Currently, there is no data or source related to Biomedical Research and Development Product Index -BRDPI- (Moses III et al. 2005, Dorsey et al. 2010).

Statistical methods: Data was analyzed on a MATLAB 7.13 platform (MathWorks, Natick, $\mathrm{MA})$. Financial trends were analyzed using a polynomial regression model. A two-tailed t-test with significance of $5 \%$ was applied to compare the periods of 2000-2006 and 2007-2012.

\section{Results}

Colombian GDP (adjusted for purchasing power parity exchange rate ratio) almost doubled between the early and late periods. STI funding ranged from $0.27 \%$ to $0.47 \%$ of the GDP while 
Table 1. Statistics summary of Colombian STI, RD and COLCIENCIAS financial budget: from 2000 to 2012. Values adjusted for purchasing power parity (US\$ PPP) exchange rate ratio. Source: The World Bank, Banco de la República, OCyT (2010, 2012), DANE and COLCIENCIAS.

\begin{tabular}{|c|c|c|c|}
\hline & $2000-2006$ & $2007-2012$ & Statistics \\
\hline $\begin{array}{l}\text { Colombian CPG } \\
\text { (Billion US Dollars) }\end{array}$ & $116.7 \pm 27.3$ & $279.0 \pm 62.2$ & $\mathrm{p}<0.001$ \\
\hline Colombian CPG growth rate ( $\%)$ & $2.91 \pm 13.07$ & $8.29 \pm 10.2$ & Non-Significant \\
\hline $\begin{array}{l}\text { STI budget } \\
\text { (Million US Dollars) }\end{array}$ & $948.0 \pm 244$ & $1,988.0 \pm 263$ & $\mathrm{p}<0.001$ \\
\hline STI budget growth rate $(\%)$ & $7.15 \pm 18.66$ & $9.5 \pm 16.28$ & Non-Significant \\
\hline Public funding $(\%)$ & $44.87 \pm 7.92$ & $53.72 \pm 6.10$ & $\mathrm{p}<0.05$ \\
\hline Private funding $(\%)$ & $51.43 \pm 8.22$ & $42.92 \pm 6.41$ & Non-Significant \\
\hline International funding ( $\%)$ & $3.69 \pm 0.99$ & $3.34 \pm 0.88$ & Non-Significant \\
\hline $\begin{array}{l}\text { RD budget } \\
\text { (Million US Dollars) }\end{array}$ & $348.6 \pm 83.0$ & $778.3 \pm 92.4$ & $\mathrm{p}<0.001$ \\
\hline RD budget growth rate ( $\%)$ & $7.74 \pm 10.7$ & $8.84 \pm 13.25$ & Non-Significant \\
\hline Public funding $(\%)$ & $52.81 \pm 4.24$ & $54.67 \pm 5.26$ & Non-Significant \\
\hline Private funding $(\%)$ & $40.64 \pm 4.18$ & $41.20 \pm 5.52$ & Non-Significant \\
\hline International funding $(\%)$ & $6.53 \pm 1.83$ & $4.11 \pm 0.47$ & $\mathrm{p}<0.001$ \\
\hline $\begin{array}{l}\text { COLCIENCIAS budget } \\
\text { (Million US Dollars) }\end{array}$ & $73.7 \pm 21.0$ & $215.4 \pm 77.5$ & $\mathrm{p}<0.001$ \\
\hline $\begin{array}{l}\text { COLCIENCIAS budget } \\
\text { growth rate }(\%)\end{array}$ & $19.92 \pm 33.2$ & $9.5 \pm 22.35$ & Non-Significant \\
\hline
\end{tabular}

RD showed a more stable pattern from $0.11 \%$ to 0.18\% (Salazar et al. 2010, Lucio et al. 2012).

Between 2007 and 2012 the STI financial budget increased significantly $(\mathrm{p}<0.001)$, as did the RD ( $\mathrm{p}<0.001)$ when compared to the 20002006 period (Table 1). As shown in Figure 1 (trends as dotted lines), STI and RD increase steadily; total funding for STI and RD doubled in the periods evaluated (Table 1). Annual growth rate for STI, RD, and COLCIENCIAS funding had an incremental tendency for both intervals.
COLCIENCIAS funding increased (adjusted for purchasing power parity US\$ exchange rate ratio) dramatically from $\$ 70.3$ US million dollars in 2000 to $\$ 323.8$ US million dollars in 2012. STI funding followed a similar trend (Figure 1); a significant increase $(\mathrm{p}<0.001)$ in the latter period (Table 1).

Private funding: The private sector contributed approximately $51.43 \%$ ( \pm 8.22) to STI from 2000 to 2006 , compared to a $42.92 \%$ ( \pm 6.41) from 2007 to $2012(\mathrm{p}=0.064)$; this indicates a decrease 


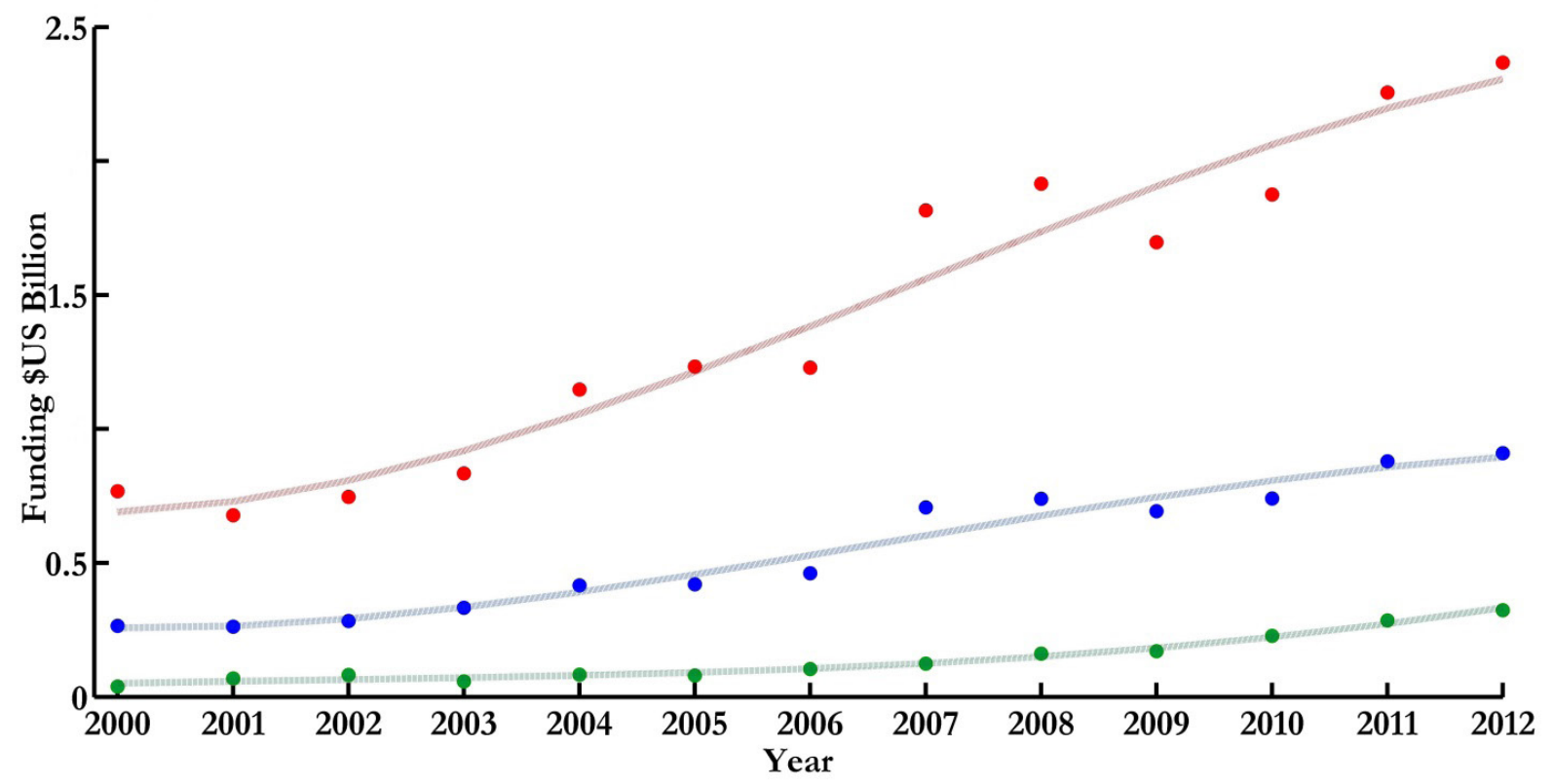

Fig. 1. STI, RD and COLCIENCIAS financial budget and trends (dotted lines): from 2000 to 2012. Values adjusted for purchasing power parity (US\$ PPP) exchange rate ratio. STI (red dots), RD (blue dots), COLCIENCIAS (green dots). Source: The World Bank, Banco de la República, OCyT $(2010,2012)$ and COLCIENCIAS.

of private funding (Figure 2). On the other hand, private contribution to RD was stable at $40.64 \%$ ( \pm 4.18) versus $41.20 \%( \pm 5.52)(\mathrm{p}=0.838)$ (Figure 3$)$.
Public funding: Political efforts described in the discussion have generated a steady growth rate in this area. STI public funding significantly increased

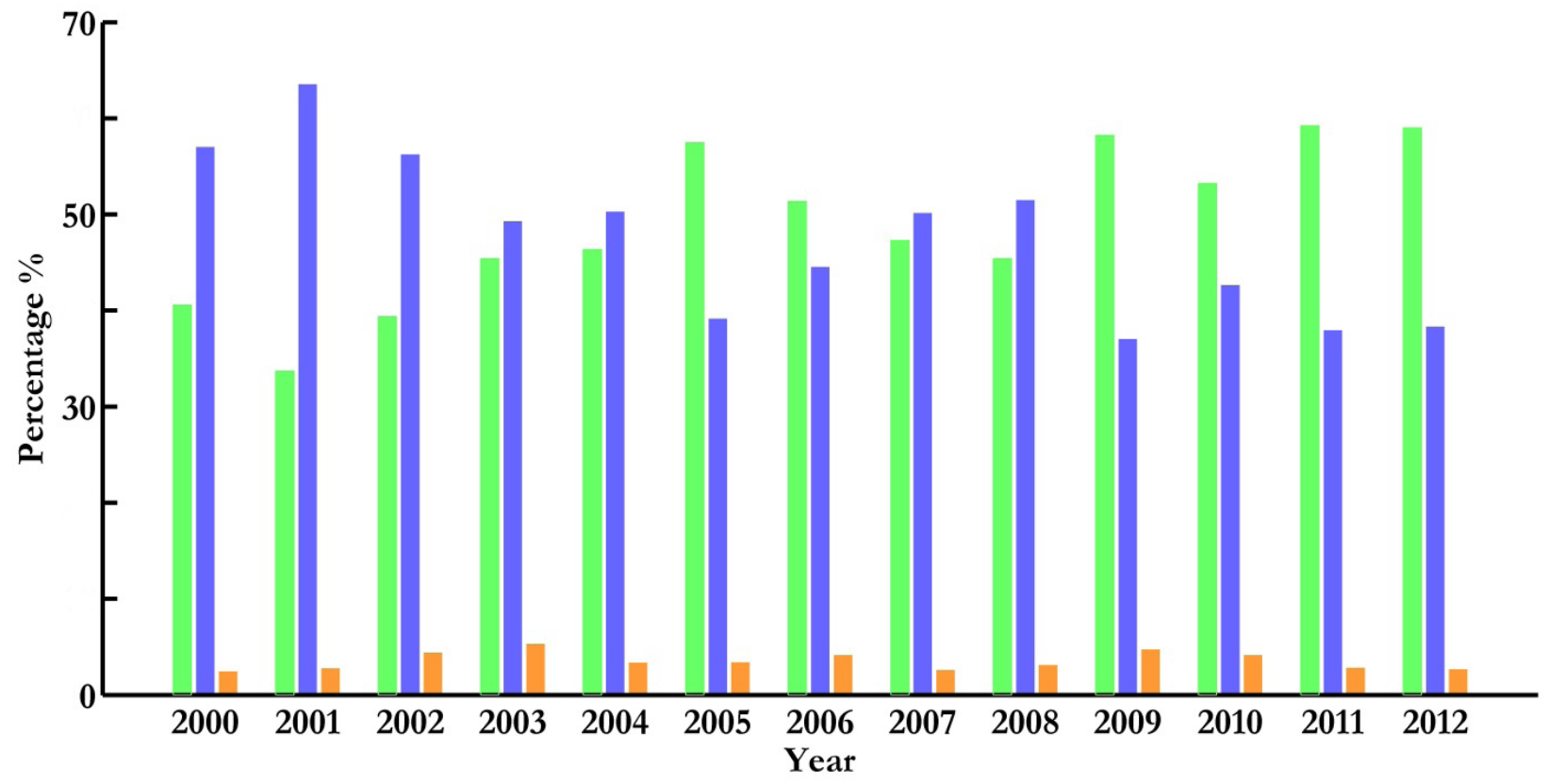

Fig. 2. STI financial budget by sector: from 2000 to 2012. Source: OCyT $(2010,2012)$. 
$(\mathrm{p}=0.0486)$ from $44.87 \%( \pm 7.92)$ in $2000-2006$ to $53.72 \%( \pm 6.10)$ in $2007-2012$ (Figure 2). By comparison, $\mathrm{RD}$ maintained a stable trend $(\mathrm{p}=$ 0.4961) (Figure 3). between 2000-2006 (6.53\% \pm 1.83$)$ and 2007-2012 $(4.11 \% \pm 4.7)$ (Figure 3). International funding of STI showed no significant change for these periods $(\mathrm{p}=0.526)$ (Figure 2$)$.

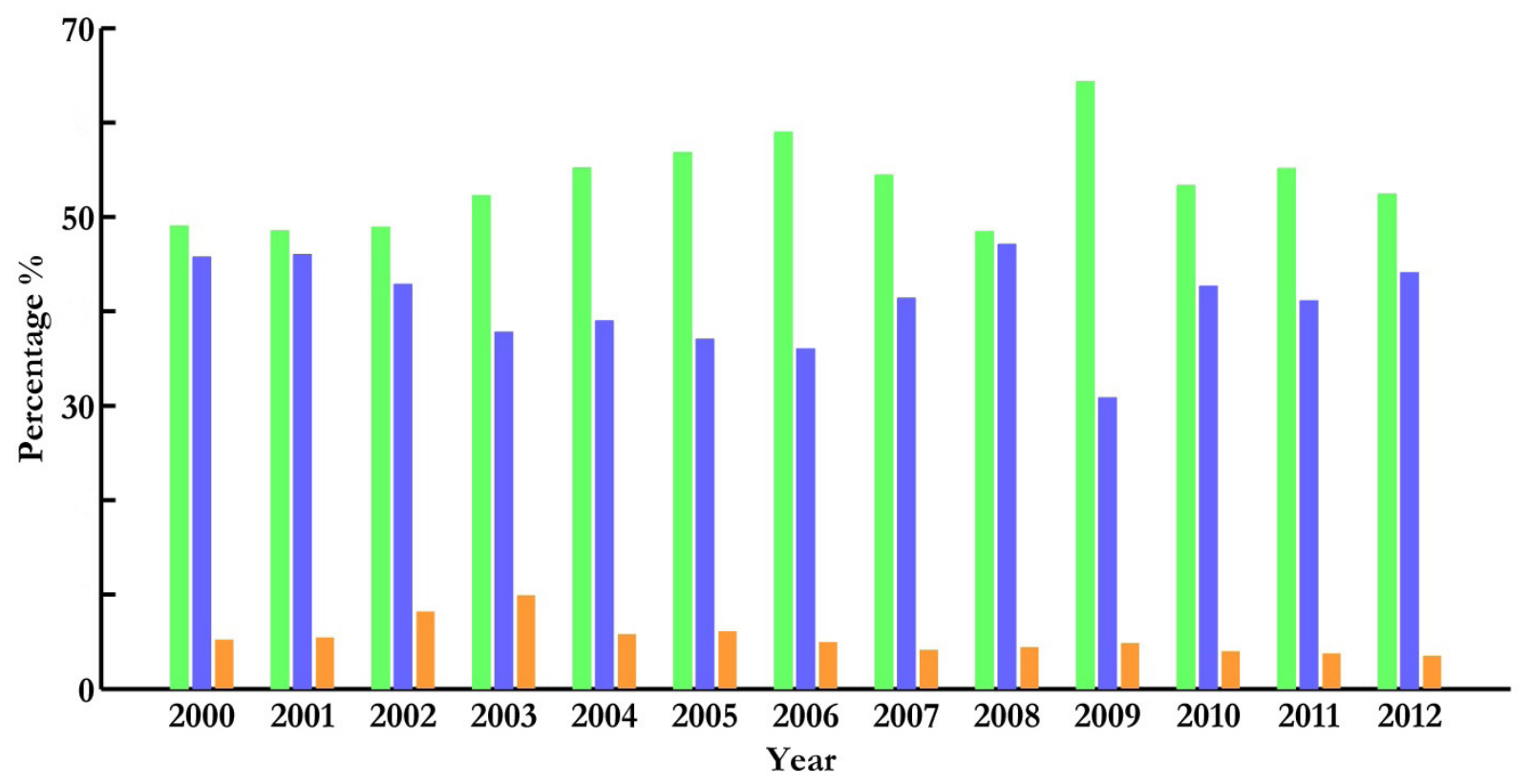

Fig. 3. RD financial budget by sector: from 2000 to 2012. Source: OCyT $(2010,2012)$.

International funding: International investment is not a significant contributor to scientific funding in Colombia; however, there was a significant decrease $(p=0.009)$ in international $R D$ funding
STI funding per institution: Government and corporations provided most of the funding resources from 2000 to 2012 (Table 2). There was a noteworthy increase $(\mathrm{p}<0.05)$ in

Table 2. Statistics of Colombian STI funding source by institution: from 2000 to 2012. Source: OCyT (2010, 2012) and DANE.

\begin{tabular}{lccc}
\hline & $2000-2006$ & $2007-2012$ & Statistics \\
\hline Firms (\%) & $45.41 \pm 8.52$ & $35.62 \pm 6.36$ & $\mathrm{p}<0.05$ \\
Government (\%) & $36.01 \pm 7.70$ & $46.28 \pm 6.05$ & $\mathrm{p}<0.05$ \\
Education institutions (\%) & $11.77 \pm 0.59$ & $10.13 \pm 0.49$ & $\mathrm{p}<0.001$ \\
International (\%) & $3.69 \pm 0.99$ & $3.34 \pm 0.88$ & Non-Significant \\
Research centers (\%) & $2.38 \pm 0.82$ & $2.47 \pm 0.32$ & Non-Significant \\
Medical centers (\%) & $0.46 \pm 0.69$ & $1.14 \pm 0.22$ & $\mathrm{p}<0.05$ \\
Private nonprofits institutions (\%) & $0.09 \pm 0.03$ & $0.65 \pm 0.29$ & $\mathrm{p}<0.001$ \\
ONG (\%) & $0.16 \pm 0.02$ & $0.33 \pm 0.11$ & $\mathrm{p}<0.01$ \\
\hline
\end{tabular}


government funding between 2007 and 2012, and a decrease $(p<0.05)$ in corporate funding, which likely contributed to the decrease in the STI private funding (Figure 2). Funding from minor sources such as medical centers $(\mathrm{p}<0.05)$, private nonprofit institutions $(p<0.001)$, and ONGs $(p<0.01)$ showed a significant increase during the
Corporations $(p=0.119)$, government $(p=0.094)$ and research center $(p=0.280)$ expenditures did not change while university expenditures decreased $(p<0.001)$. Medical centers $(p<0.05)$, private nonprofit institutions $(\mathrm{p}<0.001)$ and ONG $(p<0.01)$ expenditures showed significant increases.

Table 3. Statistics of Colombian STI expenditure by institution: from 2000 to 2012. Source: OCyT $(2010,2012)$ and DANE.

\begin{tabular}{lccc}
\hline & $2000-2006$ & $2007-2012$ & Statistics \\
\hline Firms (\%) & $42.89 \pm 7.45$ & $36.59 \pm 5.67$ & Non-Significant \\
Education institutions (\%) & $26.16 \pm 1.1$ & $22.86 \pm 1.16$ & $\mathrm{p}<0.001$ \\
Government (\%) & $16.9 \pm 7.4$ & $23.03 \pm 3.8$ & Non-Significant \\
Research centers (\%) & $10.7 \pm 2.07$ & $11.8 \pm 1.2$ & Non-Significant \\
Medical centers (\%) & $1.4 \pm 0.7$ & $2.4 \pm 0.4$ & $\mathrm{p}<0.05$ \\
Private nonprofits institutions (\%) & $1.3 \pm 0.3$ & $2.3 \pm 0.3$ & $\mathrm{p}<0.001$ \\
\hline ONG (\%) & $0.6 \pm 0.08$ & $1.03 \pm 0.3$ & $\mathrm{p}<0.01$ \\
\hline
\end{tabular}

late period. However, contributions by universities decreased $(\mathrm{p}=0.001)$ while international $(\mathrm{p}=0.527)$ and research center funding $(\mathrm{p}=0.822)$ showed no significant change.

STI expenditure per institution: Corporations, government, universities and research centers used most of STI funding (Table 3) from 2000 till 2012.
STI expend by activity: From 2000 till 2012, research and development, innovation, and scientific and technological services made up the majority of STI expenditures (Table 4). There was an increase in research and development $(p<0.05)$, support for scientific and technological training $(\mathrm{p}<0.05)$, and scientific and technological services

Table 4. Statistics of Colombian STI expenditure by activity, from 2000 to 2012. Source: OCyT (2010, 2012).

\begin{tabular}{lccc}
\hline & $2000-2006$ & $2007-2012$ & Statistics \\
\hline Research and development (\%) & $36.9 \pm 2.1$ & $39.2 \pm 0.9$ & $\mathrm{p}<0.05$ \\
Innovation (\%) & $41.4 \pm 5$ & $34.5 \pm 3.7$ & $\mathrm{p}<0.05$ \\
Support for scientific and technological training (\%) & $6.2 \pm 0.9$ & $7.5 \pm 1.3$ & $\mathrm{p}<0.05$ \\
Scientific and technological services (\%) & $6.9 \pm 3$ & $13.5 \pm 2.7$ & $\mathrm{p}<0.01$ \\
Administrative (\%) & $8.5 \pm 1.5$ & $5.2 \pm 1.5$ & $\mathrm{p}<0.01$ \\
\hline
\end{tabular}


$(\mathrm{p}<0.01)$ from 2007 to 2012. On the other hand, a significant decrease in innovation $(p<0.05)$ and administrative related activities $(\mathrm{p}<0.01)$.

\section{Discussion}

This analysis describes the funding and expenditure trends for scientific research in Colombia between 2000 and 2012. It was noticed a steady increase in funding in STI, RD and COLCIENCIAS in Colombia since 2004 (Figure 1) and a constant annual growth rate from 2000 till 2012.

A comparison of 2000-2006 and 2007-2012 showed an increase in the proportion of funding from public sources $d$ in the later period potentially caused by the economic recession in 2009. This recession may have had a more marked impact on private sector funding, which had its lowest contributions to STI $(37.03 \%)$ and RD (30.85\%) during this year (Figure 2 and Figure 3 ).

The evaluation of STI funding institutions showed that corporations and government supplied the majority of funding. In 2000, it was the corporations that provided the majority of funding (51.75\%); in 2012, perhaps due to government initiatives, the public sector has become the major funding source $(51.73 \%)$. This is consonant with what is characteristically seen in developing countries (Ladenheim 2011); public funding is a trend, which in the last century, seems to be growing due to budget volatility. Corporations, government and research centers largely fund STI expenditure (Table 3); this combined relative contribution has remained relatively constant.

As indicated by the OCyT in 2012 (Lucio et al. 2012), corporations invest most of their funding in innovative activities and research and development. Government, on the other hand, focuses on scientific and technological services and innovation activities, and research centers tend to focus mainly on research and development.

The legislative acts of the past 12 years have increased STI expenditure (Table 4) in research and development, support for scientific and technological training, and scientific and technological services, but not in innovative activities.
In 2003, an investigative study found administrative and organizational breakdowns between government institutions that were limiting public funding for innovation undertakings by small and medium-sized businesses (Landriault \& Matlin 2009). The study criticized the CSTIS claiming that legislative changes were needed to promote positive results in Colombian STI; these affirmations lead to an evaluation of government initiatives in 1990, 1991, 1992 and 2001(Landriault \& Matlin 2009).

In the past decade, legislation has increased scientific funding and reorganized Colombia's scientific budget. By 2009, the scope of COLCIENCIAS had changed; the entity's autonomy and power regarding different aspects of STI and RD has expanded. Simultaneously, communication with the CSTIS has markedly improved (Senado de la República de Colombia 2009).

In 2009, CONPES (Economical and Social Politics Council), which promotes high-value goods in scientific and technological policy, took on the promotion of STI as one of their goals, to improve collaboration with the CSTIS. A focus on energy, natural resources and biotechnology led to the creation of the Green Innovation, a program that focuses on topics such as biofuels, alternative energy, and biodiversity. Other areas such as genetic and agricultural research also benefited from the increased cooperation between the private and public sectors (Lemarchand 2010, OECD 2012). In 2010, another legislative act created the Francisco José de Caldas Fund, which generated over 138 million USD for the COLCIENCIAS budget (Restrepo Cuartas 2010).

In 2011, another significant legislative act was passed regulating the exploitation of nonrenewable natural sources. According to this act, $10 \%$ of royalty incomes will be directed to a national STI fund; in 2012, this fund totaled approximately 429 million USD (Maldonado Castañeda \& Sanchez Vargas 2012).

The current decrease in STI innovation activities $(\mathrm{p}<0.05)$ has led to political efforts to stimulate the sector. As stated by the Colombian 
National Planning Department, the promotion of small to medium Colombian businesses will lead to an increase in innovation and entrepreneurship. These ongoing efforts hope to propel Colombia's future economic competitiveness (DNP, Vision Colombia 2019).

Over the years, the diaspora of Colombian researchers has slowed, and domestic support for graduate study has greatly improved; financial aid has become accessible for many more candidates than before (Lucio et al. 2012). Similarly, in the past decade, the "Policy for Social Appropriation of STI" has increased community participation in STI. Today, the community works as an active mediator in STI regulation, by promoting the cultural value of science. Colombian society has actively influenced the selection of projects and the creation of laboratories, institutions and new programs (Lemarchand 2010).

Previous studies have shown that Latin American countries have a similar scientific and technological structure (Ribeiro et al. 2009). Despite current efforts, Colombian RD expenditure still lags behind other Latin American and developed countries (Table 5). Developed countries have at least 1\% RD GDP funding (The World Bank Group 2013b), mostly by the private sector (Wadsworth 2009, 2010, Ladenheim 2011, Wadsworth 2013). Over the last decade, Colombian funding patterns trend towards the public sector, resembling developing countries (Ladenheim 2011).

This study is based on financial trends; however, current data obscures how the STI, RD and COLCIENCIAS budget was concentrated by sector of interest (biomedical, education, environment, engineering research), addressing this issue will help to understand whether the research portfolio matches or not Colombian needs. One of the greatest challenges is to obtain $1 \%$ of the GDP for science and technology (Moses III et al. 2005, Dorsey et al. 2010, Lucio et al. 2012), but the continuous increase seen in the Colombian scientific budget will lead to improvements not just financial but also social and educational. These policies, which reflect an
Table 5. RD (GDP percentage) expenditure by country, from 2002 to 2010. Source: World Development Indicators, The World Bank. (RD)

Research and Development.

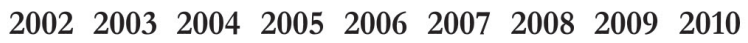

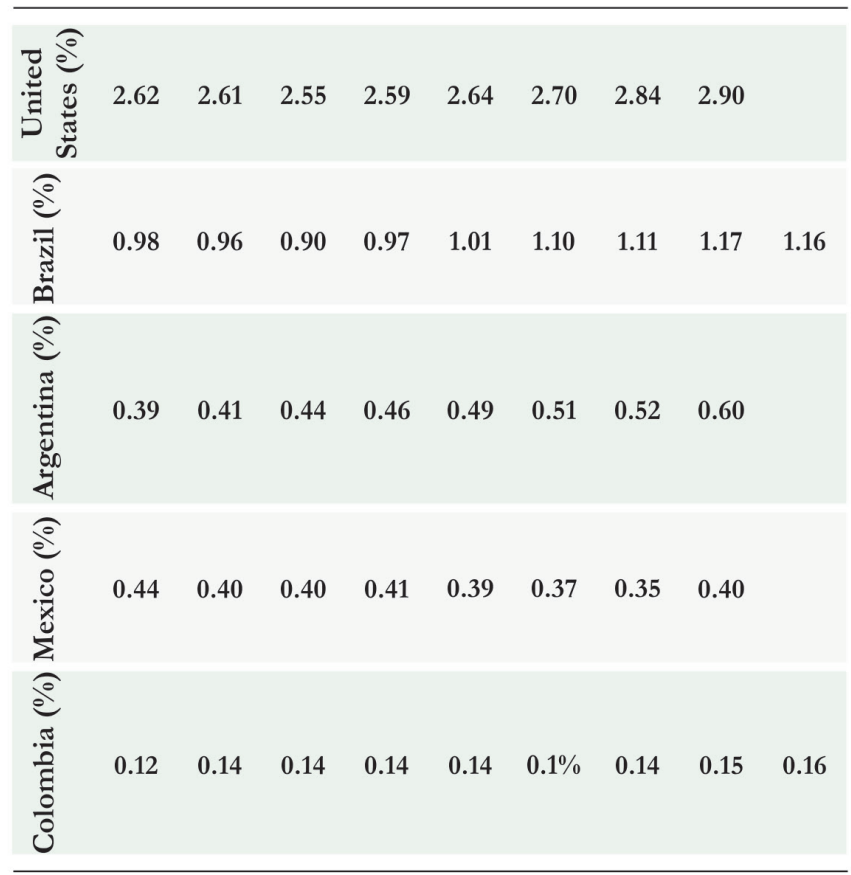

understanding of our obligation to science, may indicate a shift in our perspective of STI and RD as main actors in the development and furtherance of Colombian culture.

\section{Conclusion}

Colombian STI, RD and COLCIENCIAS funding significantly increased in the past twelve years. Today, there is increased STI funding from the public sector (government), which is characteristic of developing countries. An STI sub-categorical analysis showed that most Colombian institutions maintain a constant expenditure focused on $\mathrm{RD}$ and innovation.

\section{Acknowledgement}

I thank Dr. William Chen, Dr. Atilio Bergamini and Dr. Manuel Rodríguez for their insightful comments. 


\section{Conflict of Interest}

The author declares no conflicts of interest.

\section{References}

Bénassy-Quéré A, Roussellet G (2012) Fiscal sustainability in the presence of systemic banks: the case of EU countries. International Tax and Public Finance:1-32

Dorsey ER, de Roulet J, Thompson JP, Reminick JI, Thai A, et al (2010) Funding of US biomedical research, 2003-2008. JAMA 303(2):137-143

Frank C, Nason E (2009) Health research: measuring the social, health and economic benefits. Canadian Medical Association Journal 180(5):528-534

Garro G, Mormontoy H, Yagui M (2010) Gestión y financiamiento de las investigaciones por el Instituto Nacional de Salud, Perú 2004-2008. Revista Peruana de Medicina Experimentaly Salud Pública 27(3):361-366

Ladenheim R (2011) Indicadores de Ciencia y Tecnología Argentina 2010. In: Ministerio de Ciencia TeIP (ed), Godoy Cruz 2320, Ciudad de Buenos Aires, pp 29

Landriault E, Matlin SA (2009) Monitoring financial flows for health research 2009: behind the global numbers Global Forum for Health Research. Global Forum for Health Research, Geneva, Switzerland, pp 153-193

Lemarchand G (2010) National science, technology and innovation systems in Latin America and the Caribbean. Science Policy Studies and Documents in LAC, Montevideo, Uruguay, pp 308

Lucio J, Lucio-Arias D, Colorado L, Rivera S, Cruz D, et al (2012). Indicadores de ciencia y tecnología Colombia. http://ocyt.org.co/html/ archivosProyectos /OCyT $\% 20$ Indicadores $\% 20$ 2012.pdf. Access date January 2013

Maceira D, Paraje G, Aramayo F, Duarte Masi S, Sánchez D (2010) Financiamiento público de la investigación en salud en cinco países de América Latina. Revista Panamericana de Salud Pública 27(6):442-451

Maldonado Castañeda OJ, Sanchez Vargas D (2012) Knowledge and Politics of the Public: Elements for analyzing the rise of social innovation agenda in policy discourse in Colombia Third Forum Innovation in Governance, Berlin, Germany, pp 1-15

Martínez-Martínez E, Zaragoza ML, Solano E, Figueroa B, Zúñiga P, et al (2012) Health Research Funding in Mexico: The Need for a Long-Term Agenda. PloS one 7(12):e51195 doi 10.1371/journal. pone. 0051195
Moses III H, Dorsey ER, Matheson DH, Thier SO (2005) Financial anatomy of biomedical research. JAMA 294(11):1333-1342

North DC, Bárcena A (1993) Instituciones, cambio institucional y desempeño económico. Fondo de Cultura Económica, México, pp 190

Obregón D (1991) La Sociedad de Naturalistas Neogranadinos y la tradición científica. Anuario Colombiano de Historia Social y de la Cultura 18:101-123

OECD (2012) OECD Science, Technology and Industry Outlook 2012. OECD Publishing, pp 268-271 http://dx.doi.org/10.1787/sti_outlook-2012-en

Ospina Bozzi ML (1998) Colciencias, 30 años: memorias de un compromiso. Colciencias, Santafé de Bogotá, Colombia, pp 370

Restrepo Cuartas J (2010) Informe de gestíon: Alcance 2006-2010, pp 1-84

Ribeiro LC, Albuquerque E, Franco L, Moura I (2009) The scientific and technological trajectories of four Latin American countries: Mexico, Costa Rica, Argentina and Brazil CEDEPLAR-FACE-UFMG (manuscript prepared for the Latin American Workshop on interactions between universisities and firms), Belo Horizonte, Brasil, pp 1-23

Sachs J (2001) Macroeconomics and Health: Investing in Health for Economic Development. Macroeconomics and health: investing in health for economic development. World Health Organization. Marketing and Dissemination., 1211 Geneva 27, Switzerland, pp 210

Salazar M, Lucio J, Rivera S, Bernal E, Ruiz C, et al (2010). Indicadores de ciencia y tecnología, Colombia 2010. http://www.ocyt.org.co/html/ archivosProyectos/COLOMBIA_2010.pdf. Access date January 2013

Senado de la República de Colombia (2009). Ley 1286 de 2009. http://www.secretariasenado.gov.co/ senado/basedoc/ley/2009/ley_1286_2009.html. Access date January 2013

The World Bank Group (2013a). PPP conversion factor (GDP) to market exchange rate ratio. http:// data.worldbank.org/indicator/PA.NUS.PPPC.RF/ countries?display $=$ default. Access date June 2013

The World Bank Group (2013b). Research and development expenditure. http://data.worldbank. org/indicator/GB.XPD.RSDV.GD.ZS/ countries?page $=2 \&$ display $=$ default. Access date June 2013

Wadsworth J (2009) Global R\&D funding forecast: an overview. Research \& Development Magazine:3-36

Wadsworth J (2010) Global R\&D funding forecast: an overview. Research \& Development Magazine:3-36 
Wadsworth J (2013) Global R\&D funding forecast: an overview. Research \& Development Magazine:3-36

Yagui M, Espinoza M, Caballero P (2010) Avances y retos en la construcción del sistema nacional de investigación en salud en el Perú. Revista Peruana de Medicina Experimental y Salud Pública 27(3):387-397

\section{Presupuesto de financiación científica en Colombia del 2000 al 2012}

Resumen. Este estudio evalúa las tendencias financieras de Ciencia, Tecnología e innovación (STI), Investigación y Desarrollo (RD) y COLCIENCIAS (Departamento Administrativo de Ciencia, Tecnología e Innovación) entre el 2000-2006 y 2007-2012. Se usó información disponible del World Bank, OCyT (Observatorio Colombiano de Ciencia y Tecnología), DANE (Departamento Administrativo Nacional de Estadística), Banco de la República y COLCIENCIAS, se analizó: la fuente (privada, pública, internacional), tasa de crecimiento y ejecución financiera, así como ejecución por actividad del 2000 al 2012. Se usaron modelos de regresión para estimar tendencias financieras. La financiación Colombiana en STI, RD y COLCIENCIAS aumentó en los últimos años. La inversión en STI y RD aumentó entre 2000-2006 y 2007-2012 de \$1,296.7 a \$2.766.4 millones de dólares, respectivamente. Análisis evidenció un incremento significativo $(p<0.05)$ en la inversión pública, siendo el gobierno el principal partícipe. Sin embargo, la ejecución financiera del gobierno y empresas no mostró cambios entre 2000-2012.

Palabras clave: Investigación científica y desarrollo tecnológico; Financiación en investigación; Ciencias de la Salud; Administración de tecnología e innovación; Colombia.
Captaçáo de recursos científicos na Colômbia 2000-2012

Resumo. Este estudo avaliou as tendências financeiras da Ciência, Tecnologia e Inovação, Investigação e Desenvolvimento e COLCIENCIAS (Departamento Administrativo de Ciência, Tecnologia e Inovação), entre 2000-2006 e 2007-2012. Dados do Banco Mundial, OCyT (Observatório Colombiano de Ciência e Tecnologia), DANE (Departamento Nacional de Estatística), Banco de la República e COLCIENCIAS foram utilizados para analisar: origem do financiamento por setor (privado, público e internacional), taxa de crescimento, despesas, e atividades relacionadas às despesas, entre 2000-2012. Modelos de regressão foram utilizados para se chegar às tendências financeiras. O investimento em STI, RD e COLCIENCIAS tem crescido nos últimos anos. O investimento em Ciência, Tecnologia e Inovação,e Investigação e Desenvolvimento aumentou de US \$1,296.7 milhões de dólares em 2000-2006 para US \$2,766.4 milhões de dólares em 2007-2012. A análise mostrou um aumento significativo no financiamento público $(\mathrm{p}<0,05)$, mesmo que as despesas do governo e das empresas não se tenham alterado entre 2000-2012.

Palavras-chave: Investigação científica e desenvolvimento tecnológico; Financiamento de investigação; Ciências da saúde; Tecnologia e gestão da inovação; Colômbia. 